Research, part of a Special Feature on Do we need new management paradigms to achieve sustainability in tropical forests?

\title{
Tropical Deforestation, Community Forests, and Protected Areas in the Maya Forest
}

\author{
$\underline{\text { David Barton Bray }}^{1}$, Elvira Duran $^{2}$ Victor Hugo Ramos $^{3}$, Jean-Francois Mas $^{4}$, Alejandro Velazquez $^{4}$, \\ $\underline{\text { Roan Balas McNab }}^{3}$, Deborah Barry ${ }^{5}$, and Jeremy Radachowsky ${ }^{6}$
}

\begin{abstract}
Community forests and protected areas have each been proposed as strategies to stop deforestation. These management strategies should be regarded as hypotheses to be evaluated for their effectiveness in particular places. We evaluated the community-forestry hypothesis and the protected-area hypothesis in community forests with commercial timber production and strict protected areas in the Maya Forest of Guatemala and Mexico. From land-use and land cover change (LUCC) maps derived from satellite images, we compared deforestation in 19 community forests and 11 protected areas in both countries in varying periods from 1988 to 2005. Deforestation rates were higher in protected areas than in community forests, but the differences were not significant. An analysis of human presence showed similar deforestation rates in inhabited protected areas and recently inhabited community forests, but the differences were not significant. There was also no significant difference in deforestation between uninhabited protected areas, uninhabited community forests, and long-inhabited community forests. A logistic regression analysis indicated that the factors correlated with deforestation varied by country. Distance to human settlements, seasonal wetlands, and degree and length of human residence were significant in Guatemala, and distance to previous deforestation and tropical semideciduous forest were significant in Mexico. Varying contexts and especially colonization histories are highlighted as likely factors that influence different outcomes. Poorly governed protected areas perform no better as a conservation strategy than poorly governed community forests with recent colonists in active colonization fronts. Long-inhabited extractive communities perform as well as uninhabited strict protected areas under low colonization pressure. A review of costs and benefits suggests that community forests may generate more local income with lower costs. Small sample sizes may have limited the statistical power of our comparisons, but descriptive statistics on deforestation rates, logistic regression analyses, LUCC maps, data available on local economic impacts, and long-term ethnographic and action-research constitute a web of evidence supporting our conclusions. Long-inhabited community forest management for timber can be as effective as uninhabited parks at delivering long-term forest protection under certain circumstances and more effective at delivering local benefits.
\end{abstract}

Key Words: community forest management; Guatemala; land-use and land cover change analysis; logging; Mexico; protected areas

\section{INTRODUCTION}

Debates over optimal land-use strategies in varying circumstances for the protection of tropical forests have been sharpened by the results of recent studies that show that various types of community management are compatible with forest maintenance and biodiversity conservation (Ruiz-Pérez et al.
2005, Hayes 2006, Nepstad et al. 2006). The many emerging forms of community management, representing varying degrees of control over forest access, now allow the systematic testing of what we call the community-forestry hypothesis and the protected-area hypothesis. The community-forestry hypothesis posits that giving greater control to those people who are historically dependent on forests

${ }^{1}$ Florida International University, ${ }^{2}$ Centro Interdisciplinario de Investigacion para el Desarrollo Integral Regional, Unidad Oaxaca, ${ }^{3}$ Wildlife Conservation Society-Guatemala, ${ }^{4}$ Universidad Autonoma de Mexico, ${ }^{5}$ Center for International Forestry Research, ${ }^{6}$ University of Florida 
would improve their livelihoods and reduce deforestation. This hypothesis has been proposed frequently (Molnar et al. 2004), but until recently, its evaluation relied mostly on anecdotal evidence and case studies. The protected-area hypothesis, which posits that strict protected areas (PAs) are the most effective barrier against deforestation, must also be regarded as a testable proposition, with contradictory evidence reported to date (Bruner et al. 2001, Curran et al. 2004).

Both management forms have expanded in recent decades. In the past 25 years, > 100,000 PAs have been established, accounting for $11.5 \%$ of the global terrestrial area (Naughton-Treves et al. 2005). In a similar period, $11 \%$ of global forests have been legally devolved to local governments and communities in varying forms of traditional and emerging common property; this proportion is thought to be increasing (Arnold 1998, White and Martin 2002). These similar percentages show the increasing significance of each strategy, both for all terrestrial areas and for forests, and indicate the need for more systematic evaluations of varying forms of these two management strategies in meeting environmental and social goals. Thus, we used remote-sensing evidence to examine the relative effectiveness of community commercial timber management versus strict PAs in reducing deforestation. Community commercial timber management is common in Mexico and the Petén of Guatemala, and strict PAs were defined as the nuclear areas of biosphere reserves in the Maya Forest of Mexico and Guatemala (Primack et al. 1998). We also examined various possible influencing factors in addition to management status. We placed our findings in a broader context by discussing the differences in colonization history and the impacts of community forests and PAs on local income generation, poverty alleviation, and biodiversity conservation (Adams et al. 2004).

Logging is a particularly contentious issue in the dialogue on PAs and community forests, so we briefly discuss community management for timber production because it has received very little attention as a vehicle for forest conservation. Community logging is frequently conflated with failed integrated conservation and development projects and lumped with indirect approaches to conservation that rarely work (Ferraro and Kiss 2002, McShane and Wells 2004). The potential for community sustainable forest management has also been dismissed (Hardner and Rice 1999). These objections do not take into account the high market value of timber and Mexico's long experience with large-scale community logging. The Mexican experience suggests that community logging can conserve forest cover and biodiversity while alleviating poverty (Bray et al. 2004, 2007). In addition to Mexico, there are emerging community and organized small-holder logging experiences in the Guatemalan Petén and the Brazilian Amazon with reports of positive social and ecological impacts (Gretzinger 1998, Campos and Nepstad 2006).

Sustainable tropical forest management in general has been considered economically and ecologically impossible and thus inadvisable (Bowles et al. 1998). However, this case has been largely built on Bolivian industrial concessions on public lands and ignores the influence of forest tenure and governance regimes on logging. Putz et al. (2000) have analyzed logging by types of silvicultural practices, but logging should also be analyzed by forms of tenure. Logging by industry on public lands, by nonindustrial private owners, and by communities are all embedded in different institutional contexts with different incentives and discount rates. Local institutions mediate not only deforestation (Gibson et al. 2000), but also logging regimes. Communities may have different management costs, extract both subsistence and cash values from their forests, factor in bequest values, and accept low discount rates that can result in very different spatial and temporal patterns of land cover clearing and forest change when compared to private industries and governments (Bray 2004). Also, low-intensity logging has relatively little impact on forest dynamics, recovery, and most biodiversity (Putz et al. 2000, Radachowsky et al. 2004).

Naughton-Treves et al. (2005) proposed land-use dynamics in buffer zones as a new research frontier for protected area effectiveness. However, the larger new frontier in land-use dynamics is in evaluating a variety of forms of protection and sustainable uses in larger landscapes beyond buffer zones. The most appropriate comparison to PAs is not no protection, which is commonly the case in most buffer zones, but rather community management (Bhagwat et al. 2001). The emergence of varieties of community forest management such as extractive reserves, indigenous territories, family forests, community concessions, and forest ejidos (a Mexican form of state-created common property) now allows for 
more rigorous comparisons with strict PAs as to their costs and benefits for forest cover maintenance, biodiversity protection, and poverty alleviation (Ruiz-Pérez et al. 2005, Hayes 2006, 2007, Nepstad et al. 2006). For example, Nepstad et al. (2006) found that indigenous territories in Brazil may be more effective at inhibiting deforestation and forest fires than are protected areas in active colonization fronts.

In the Maya Forest, existing evidence suggests that forests under community logging regimes are as effective as strict PAs at inhibiting deforestation. In Mexico, deforestation in communities under secure ejido land tenure is similar to or lower than that in PAs (Bray et al. 2004, Durán et al. 2005). The Calakmul Biosphere Reserve region of Mexico, which includes logging communities, has relatively low deforestation (Chowdhury and Schneider 2004). By contrast, two parks in the Maya Biosphere Reserve of Petén, Guatemala, lost 11.5 and $8.1 \%$ of forest cover, respectively, between 1986 and 2004, with forest loss thought to be accelerating and considerable tensions around forest uses. However, the multiple-use zone, which was dominated by community logging concessions, lost only $2.7 \%$ of forest cover and allowed fewer illegal settlements (Consejo Nacional de Areas Protegidas/Wildlife Conservation Society 2004). A critical difference between the two countries is colonization. Largescale small farmer colonization has largely subsided in Mexico, but intense colonization pressure remains in the Petén, suggesting the need for an evaluation of the effects of both management-status and human-presence variables on deforestation.

To test the community-forestry and protected-area hypotheses, we compared deforestation rates with respect to management status and human presence, as well as biophysical variables such as soils and seasonal wetland forests that may also influence deforestation. Spatial representations of colonization fronts and qualitative analyses helped to elucidate relationships between the different colonization histories and deforestation. We hypothesized that community forests are effective in inhibiting deforestation in areas that have active colonization fronts and that there is little difference between the two management strategies in situations of low colonization pressure, biophysical variables being equal. Therefore, we expected that in Mexico, deforestation rates would be similarly low in both PAs and community forests, whereas in Guatemala, deforestation would be higher in PAs than in community forests. Thus, we examined land-use and land cover change dynamics in case studies of community forests and protected areas, using specific selection criteria, in two different national contexts in the Maya Forest. We did not examine unprotected, noncommunity areas because we wanted to directly evaluate comparative outcomes of the two management models chosen in one of the few world regions that offers such a direct comparison and because of the broad policy relevance. In our discussion, we introduce a wider context for our findings by analyzing some of the broader social variables that may be influencing our results and discuss the available literature and propose further research on the costs and benefits of community forests and protected areas for local peoples.

\section{METHODS}

We chose the Maya Forest of Mexico and Guatemala (Fig. 1) for three reasons. First, they have broadly similar biophysical features like elevation, rainfall, geology, soils, and vegetation, as well as histories of forest extraction. Second, they have two of the most mature experiences in community tropical forest management for timber globally, which have been underway since the mid-1980s in Quintana Roo, Mexico, and since the mid-1990s in Guatemala. Third, they have the second largest cluster of biosphere reserves in the Western Hemisphere (Primack et al. 1998). Two of five reserves were analyzed: the Maya Biosphere Reserve (MBR) in the Petén, established in 1990; and the Calakmul Biosphere Reserve in Campeche, Mexico, established in 1989.

In Guatemala, the protected areas (PAs) and the community concessions are both part of the MBR, which consists of a core area of 10 parks (some classified as biotopes), a heavily deforested buffer zone (Hayes et al. 2002), and a multiple-use zone. The multiple-use zone includes the community concessions granted between 1994 and 2002 and other multiple uses, which include communities without concessions, two industrial concessions, and uninhabited areas (Fig. 1). Only the community concessions were analyzed here. The study sites in Mexico were the Calakmul Biosphere Reserve (hereafter Calakmul) and seven forest ejidos in central and southern Quintana Roo (Table 1). To evaluate the human presence variables and, indirectly, colonization pressure, we classified the 
Fig. 1. The Maya Forest of Mexico and Guatemala, with the locations of the protected areas and community forests analyzed. Used with permission from Consejo Civil Mexicano para la Silvicultura Sostenible.

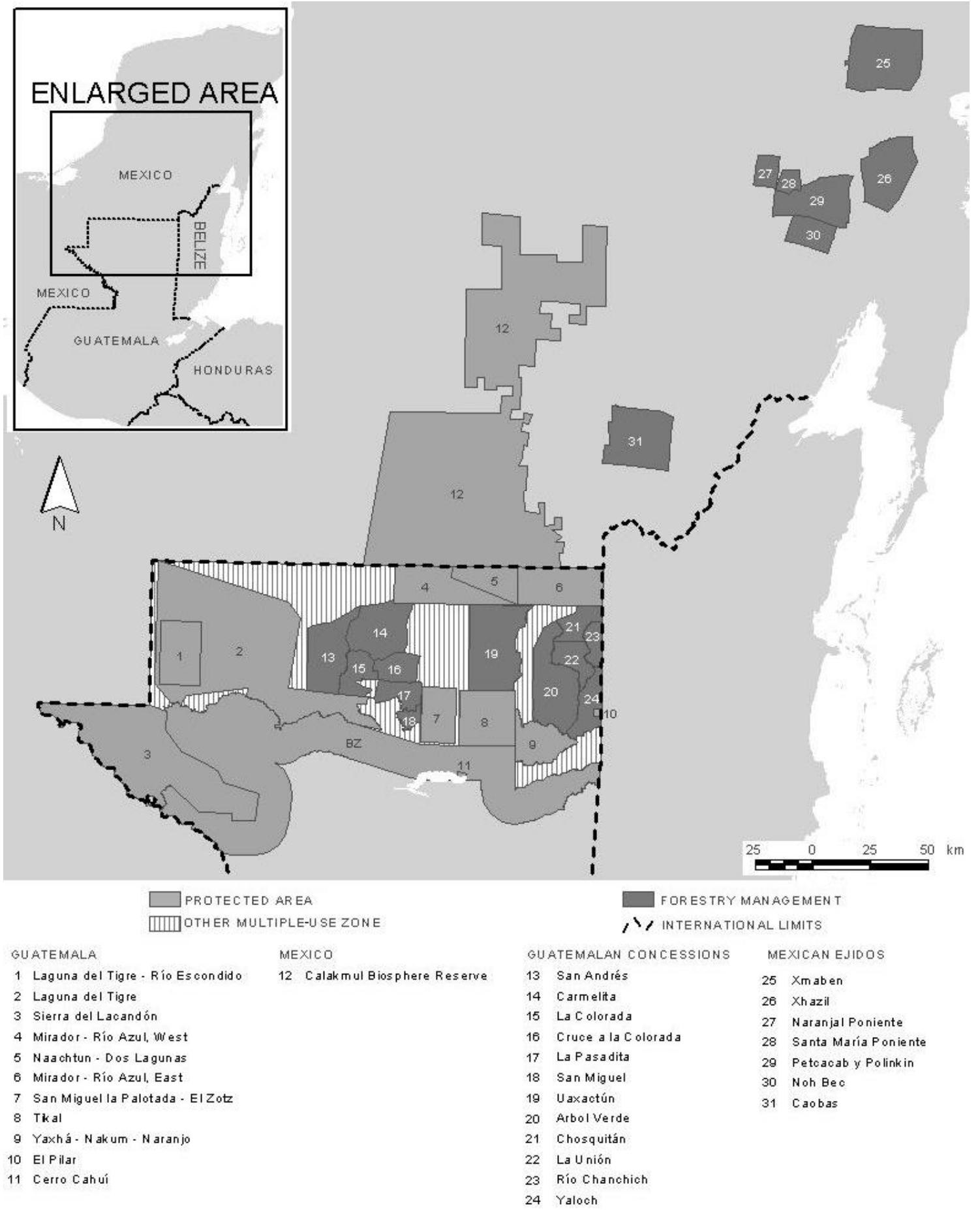


PAs in Guatemala as "uninhabited" and "inhabited" (Table 1). Uninhabited parks included those that are actually uninhabited, as well as lightly inhabited ones with very low demographic pressure. Inhabited parks are under high pressure from colonization and population growth (Grandia 2006). We classified the Guatemalan community concessions as "uninhabited" (none were lightly inhabited), "recently inhabited" ( 30 yr) and "long-inhabited" ( 100 yr). In Mexico, Calakmul has very low population density and colonization pressure, so we classified it as "uninhabited." Although Calakmul has a technically defined core and buffer zone, they were analyzed together because deforestation is not allowed in either case and they exhibit similar patterns of low deforestation (Vester et al. 2007). We selected forest ejidos with at least $80 \%$ of their total area under timber management in 2000 and with an authorized volume of logged mahogany > $300 \mathrm{~m}^{3} /$ year at an intensity of approximately $1 \mathrm{stem} /$ ha. These communities were established from 70 to $>100 \mathrm{yr}$ ago, so we classified them as "longinhabited." The land-use and land cover mosaic in the sample units contained tropical semideciduous forest as the prevailing native vegetation, with secondary succession patches, clearings for annual crops, and pasture for cattle. There were no agroforestry crops such as coffee that would make the forest vs. nonforest analysis particularly challenging.

For the land-use and land cover change analyses, we overlaid land-use and land cover maps derived from satellite images for two different dates: $t_{1}$ and $t_{2}$. For Guatemala, we used mosaics of Landsat Enhanced Thematic Mapper (ETM) satellite images for the period of $2000\left(t_{1}\right)$ to $2005\left(t_{2}\right)$. We chose the first date because a critical mass of forest concessions was not active until 2000. We classified satellite images using a normalized difference vegetation index, using the unsupervised classification method ISODATA (Hayes and Sader 2001). For Mexico, we used digital Landsat images geo-referenced and projected in the Universal Transverse Mercator NAD27 system. For communities, we analyzed satellite image mosaics for $1990\left(t_{1}\right)$ and $2000\left(t_{2}\right)$ and for Calakmul in 1988 and 2000. In both Mexican cases, the initial date images were free-access Landsat Thematic Mapper (Global Land Cover Facility Earth science data interface: http://glcfapp.umiacs.umd.edu:8080/esdi/ index.jsp); the difference in the $t_{1}$ date was because of image availability. For the second date $\left(t_{2}\right)$, Landsat ETM satellite images from the Mexican
National Forestry Inventory of 2000 were used (Palacio-Prieto et al. 2000). We carried out semiautomatic satellite image classifications, combining visual interpretation and digital classification with Geovis software (von Hagen 2005), with pixel size adjusted to $30 \mathrm{~m}$. Although the differences among the periods analyzed is not ideal, it was dictated by the available data and the empirical realities of the management units studied.

In both countries, we paid special attention to the classification procedures distinguishing native vegetation, anthropogenic land uses, and water bodies. We then overlaid $t_{1}$ and $t_{2}$ classified images to produce change maps. To avoid errors, we used identical borders, the same cartographic projection, and full comparability among vegetation types (i.e., classification scheme) between $t_{1}$ and $t_{2}$ to reach full cartographic compatibility. Map overlay and statistics were performed using Arc/Info GIS version 8.1 (Environmental Systems Research Institute).

The $t_{1}$ and $t_{2}$ overlay allowed us to identify deforestation (a change from any vegetation cover to any anthropogenic use), revegetation (the opposite of deforestation), and the permanence of native vegetation covers and anthropogenic uses (Velázquez et al. 2003), with water bodies excluded. We obtained conversion rates for each process using the following equation (Food and Agriculture Organization 1996):

$$
r=1-\left(1-\frac{S_{1}-S_{2}}{S_{1}}\right)^{1 / n}
$$

where $r$ is the rate of conversion, $S_{1}$ is the surface of cluster $x$ at date $t_{1}, S_{2}$ is the surface of cluster $x$ at date $t_{2}$, and $n$ is the difference in years between both dates.

We compared deforestation rates in PAs and communities only within their boundaries. It was not possible to use a buffer zone approach because many of the management units border similarly managed units, e.g., parks bordering parks or parks bordering community forests, but see Mas (2005) 
Table 1. Maya Forest protected areas and community forestry management units by legal status, human presence, and country.

\begin{tabular}{|c|c|c|c|}
\hline \multirow[t]{2}{*}{ Legal status } & \multirow[t]{2}{*}{ Human presence } & \multirow[b]{2}{*}{ Management unit } & \multirow{2}{*}{$\frac{\text { Mexico }}{\text { Management unit }}$} \\
\hline & & & \\
\hline \multirow[t]{2}{*}{ Protected area } & $\begin{array}{l}\text { Uninhabited to lightly } \\
\text { inhabited }\end{array}$ & $\begin{array}{c}\text { Dos Lagunas } \\
\text { Cerro Cahui Biotope } \\
\text { El Pilar Cultural Monument } \\
\text { Mirador-Río Azul National Park, West } \\
\text { Tikal National Park }\end{array}$ & $\begin{array}{c}\text { Calakmul Biosphere } \\
\text { Reserve }\end{array}$ \\
\hline & Inhabited & $\begin{array}{c}\text { Laguna del Tigre-Río Escondido Biotope } \\
\text { Laguna del Tigre National Park } \\
\text { San Miguel La Palotada-El Zotz Biotope } \\
\text { Sierra del Lacandon National Park } \\
\text { Yaxha Nakum National Park }\end{array}$ & - \\
\hline \multirow[t]{3}{*}{ Community forest } & Uninhabited & $\begin{array}{c}\text { Chosquitán } \\
\text { La Unión } \\
\text { Rio Chanchich } \\
\text { San Andres } \\
\text { Yaloch } \\
\text { Arbol Verde (Ventanas) }\end{array}$ & - \\
\hline & Long inhabited & $\begin{array}{l}\text { Carmelita } \\
\text { Uaxactún }\end{array}$ & $\begin{array}{c}\text { Caobas } \\
\text { Naranjal Poniente } \\
\text { Noh Bec } \\
\text { Petcacab } \\
\text { Santa Maria Poniente } \\
\text { X-Hazil and Anexos } \\
\text { X-Maben }\end{array}$ \\
\hline & Recently inhabited & $\begin{array}{c}\text { Cruce a la Colorada } \\
\text { La Colorada } \\
\text { La Pasadita } \\
\text { San Miguel }\end{array}$ & - \\
\hline
\end{tabular}

for a buffer zone approach to Calakmul. We spatially displayed land-use and land cover change maps to depict deforestation frontiers, forest recovery, and the permanence of forest and other native vegetation covers (Fig. 2). Because of the small sample size, we conducted nonparametric analyses to compare deforestation ratios between PAs and community forests (Siegel and Castellan 1995).

Our remote sensing methods did not allow for the recognition of different stages of secondary succession, but secondary succession in the ejidos in Mexico is mostly confined to the zoned agricultural areas in a shifting agricultural mosaic.
In the Calakmul region, Chowdhury and Schneider (2004) found that deforestation for shifting cultivation is increasingly focused in areas of secondary succession, not in mature forest inside the protected area. As well, secondary succession constituted $<10 \%$ of the land cover in 1997 , including areas located outside the Calakmul boundaries (Chowdhury and Schneider 2004). In the Maya Biosphere Reserve, active deforestation began only in 1986, with rapid expansion after that, and there is thought to be relatively little secondary succession. Although our methods may overestimate mature forest, this does not appear to be a significant problem. 
Fig. 2. Maps of land-use and land cover change processes for protected areas and community forests and the respective period analyzed. In Mexico: (A) six ejidos en Quintana Roo, (B) one ejido in Quintana Roo (Caobas), (C) Calakmul Biosphere Reserve in Campeche. In Guatemala: (D) Maya Biosphere Reserve; white areas indicate that no information was available. Used with permission from Consejo Civil Mexicano para la Silvicultura Sostenible.

A) Six ejidos - Mexico (1990-2000)

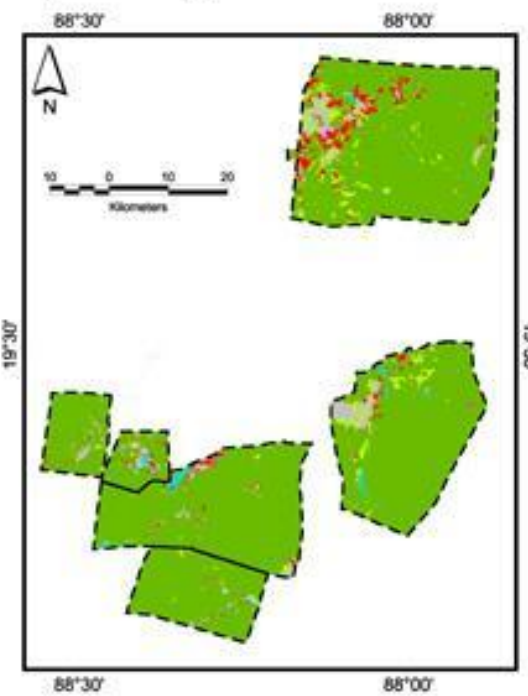

D) Maya Biosphere Reserve - Guatemala (2000-2005) 9130
B) One ejido (Caobas) - Mexico (1990-2000)

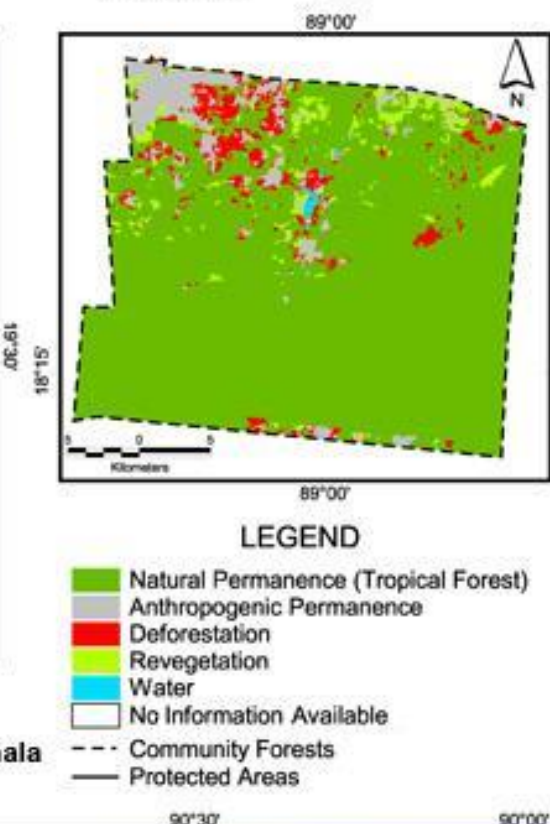

C) Calakmul Biosphere Reserve - Mexico (1988-2000)

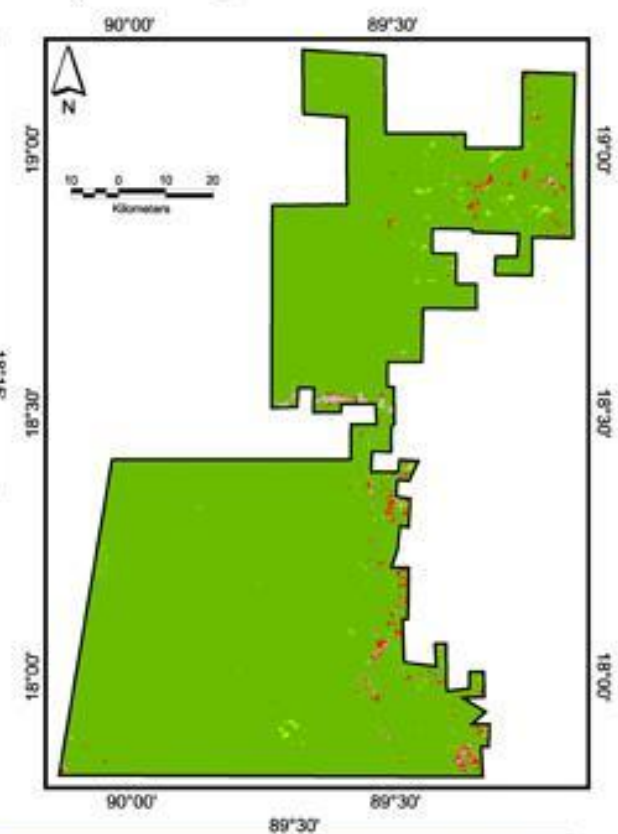

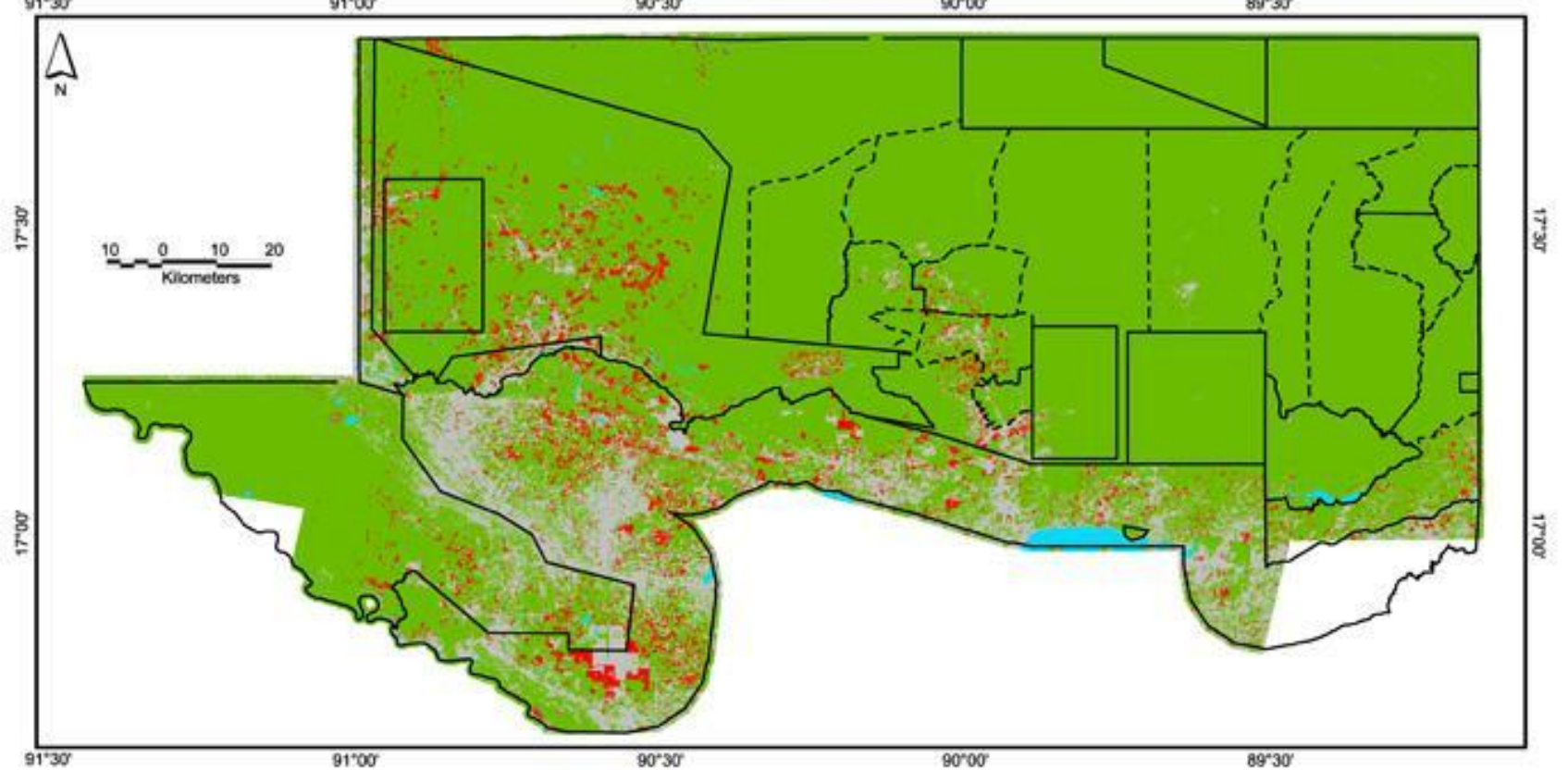


We explored the relative influence of management status, human presence, and biophysical variables in explaining deforestation using logistic regression analyses. The country regression analyses were similar, but were based on different variables because of the different contexts and digital data availability; however, in both cases, the variables used are recognized as drivers of deforestation. In Guatemala, we used 10 independent and uncorrelated spatial variables. The four continuous variables (in natural logarithm) were topographic humidity index (nondimensional), distance to permanent human settlements $(<2000$ inhabitants $)$, deforested areas before 2000, and roads. The six dummy variables were seasonal wetlands, soil depth, recently inhabited concessions, buffer zone, inhabited multiple-use zone (not under concession), and inhabited PA. In Mexico, we used five independent and uncorrelated spatial variables. These were one continuous variable of distance to deforested areas (in logarithm), two dummy variables for the native vegetation types of tropical semideciduous forest and low tropical semideciduous forest in seasonal wetlands, and two variables for management status of PA and ejido.

To avoid the spatial autocorrelation problems that may affect the explanation of deforestation (i.e., a change in forested pixels at $t_{1}$ to deforested pixels at $t_{2}$ ) by independent variables, we selected a systematic sample of pixels that were separated by a minimum distance of $400 \mathrm{~m}$ for Mexico (3000 samples) and $1000 \mathrm{~m}$ for Guatemala (3053 samples). Values of Moran's I coefficient $<0.5$ (Moran 1950) allowed for the selection of sampling points that were sufficiently far apart to represent independent samples, excluding previously deforested areas and water bodies. Arc/Info and Access were used to manage GIS and tabular databases, respectively. We analyzed the importance of independent variables by examining the partial difference of the log-likelihood for the model ( -2 log likelihood ratio) when each variable was dropped from the equation. We assessed the relationship between deforestation rates and spatially independent variables using the chi-square test and the logistic regression model.

\section{RESULTS}

Across the Maya Forest of both Mexico and Guatemala, the mean annual deforestation rate for all community forests was $-0.163 \%(0.411 \%$ SD) and that for all protected areas (PAs) was $-0.327 \%$ $(0.511 \% \mathrm{SD})$; the difference was not significant $(U$ $=95, p=0.703)$. Examining the results by country, in the Guatemalan Maya Biosphere Reserve (MBR), the mean annual deforestation rate in all community concessions was $-0.243 \%(0.474 \%$ SD), whereas that in all PAs was $-0.356 \%(0.529 \%$ SD), and the difference was not significant $(U=56$, $p=0.821)$. In Mexico, the mean annual deforestation rate for all seven community forests (ejidos) was $-0.024 \%(0.244 \%$ SD), which was approximately half of that in Calakmul, which had a deforestation rate of $-0.043 \%$. Because Calakmul was a single PA, we could not test for significance.

Human presence influenced deforestation in both community forests and PAs. There were two notable findings (Fig. 3). First, inhabited PAs and recently inhabited community forests had similar deforestation rates, i.e., $-0.694 \%(0.586 \%$ SD) and $-0.716 \%$ $(0.613 \% \mathrm{SD})$, respectively, and the difference was not significant $(U=8, p=0.730)$. Because all of these cases were located in the MBR and no such cases exist in Mexico, the results may be attributed to high colonization pressure operating on both types of management units. Second, the deforestation rate in uninhabited PAs was $-0.022 \%$ $(0.037 \%$ SD), that in uninhabited community forests (present only in Guatemala) was $-0.003 \%(0.002 \%$ $\mathrm{SD})$, and that in long-inhabited community forests (present in both countries) was $-0.023 \%(0.211 \%$ SD). Deforestation was thus similarly low in all cases in which either the management unit was uninhabited or long-inhabited in the case of community forests (there were no cases of longinhabited PAs). The difference in deforestation rates across both countries between uninhabited PAs and uninhabited community forests was not significant $(U=12, p=0.394)$, as was that between uninhabited PAs and long-inhabited communities $(U=24, p=$ 0.776).

For within-country differences, in the MBR, uninhabited PAs had a deforestation rate of $-0.018 \%(0.039 \%$ SD) and inhabited PAs had a deforestation rate of $-0.694 \%(0.586 \%$ SD). This difference was significant $(U=1, p=0.016)$. There was no significant difference between uninhabited PAs and uninhabited community concessions $(U=$ $6, p=0.126$ ) or between uninhabited PAs and longinhabited communities $(U=2, p=0.381)$.

The change maps exhibited clear spatial variation in deforestation (Fig. 2). Over a 10-yr period, the 
Fig. 3. Mean annual deforestation rates and standard deviation in protected areas and community forests in the Maya Forest of Mexico and Guatemala by human presence: uninhabited, inhabited, recently inhabited, and long inhabited.

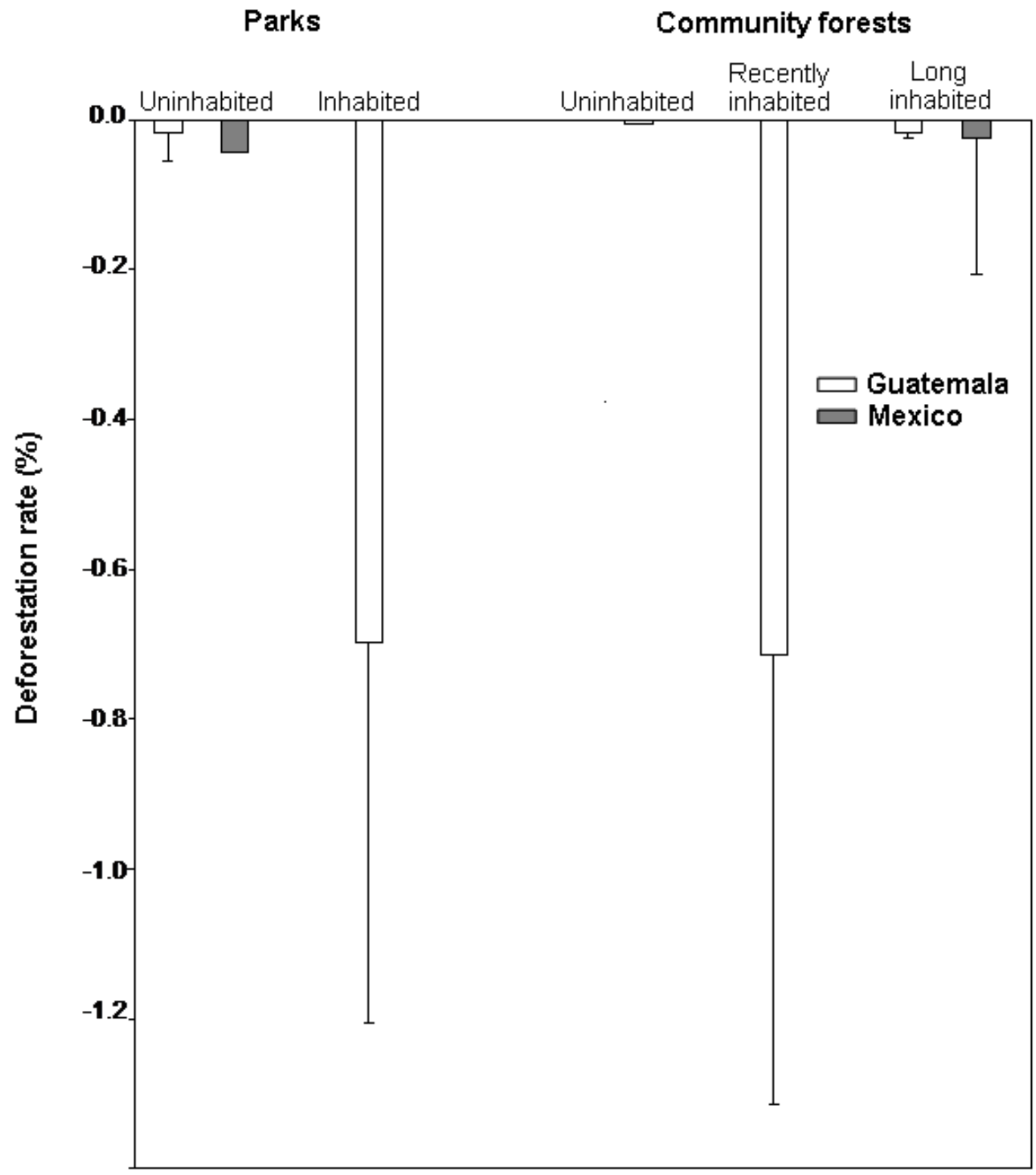


seven Mexican ejidos tended to show relatively small areas of spatially concentrated deforestation. There were large amounts of continuous unfragmented forests and some forest recovery, which likely resulted from shifting cultivation in zoned agricultural areas. In Calakmul, over a 12-yr period, a large well-conserved forest mass was present, and small amounts of deforestation and forest recovery were confined to the eastern borders, where community lands still exist, as well as to a central east-west highway.

In the MBR, over a 5-yr period, the map shows a heavily deforested buffer zone and widely distributed deforestation in the west and centersouth, but permanent large forest masses in the center-north and eastern regions (Fig. 2D). The rapidity and permanence of deforestation in the MBR means that little forest recovery occurs. The conserved regions in the east and center-north include the long-inhabited concessions, uninhabited concessions, and uninhabited parks, as well as uninhabited multiple-use zone. The western region shows spreading deforestation in the three contiguous inhabited PAs of Laguna del Tigre, Sierra del Lacandon, and Laguna del Tigre-Rio Escondido. The center-south region also shows spreading deforestation in three of the recently inhabited concessions, i.e., La Pasadita, Cruce de la Colorada, and La Colorada, as well as in the nonconcessioned multiple-use zone; the also recently inhabited San Miguel appears to be resisting deforestation along its borders.

In the logistic regression analyses (Table 2), the most important variables for explaining deforestation in Guatemala were distance to human settlements and seasonal wetlands (bajos). Deforestation was also consistently related to inhabited buffer zone, multiple-use zone without concessions, inhabited PAs, and recently inhabited community concessions. In Mexico, the only two important variables were distance to previously deforested areas (for crops and settlements) and presence of tropical semideciduous forest. The relationship with management status was nonsignificant. Regression analyses for both countries demonstrated significant predictive value in establishing explanatory variables for susceptibility to future deforestation (Table 3).

\section{DISCUSSION}

We originally hypothesized that community forests are more effective than protected areas (PAs) at inhibiting deforestation in areas with active colonization fronts and that there is little difference between the two management strategies in situations of low colonization pressure. Across both countries, we found that the deforestation rate for community forests was approximately half that for protected areas, but the difference was not significant. In the Maya Biosphere Reserve (MBR), we found that community forests had approximately one-third lower deforestation rates than did PAs, but the difference was also not significant. In the Mexican part of the Maya Forest, we found that deforestation in the ejidos was half that in Calakmul, although both were quite low, as anticipated. Testing for human presence, we found very similar and relatively high deforestation rates in inhabited PAs and recently inhabited community forests, which cases only occurred in the MBR, and the differences were not significant. We also found very similar and quite low deforestation rates between uninhabited PAs, uninhabited community forests, and long-inhabited community forests, but the differences were also not significant. The only statistically significant difference that we found was between uninhabited and inhabited PAs in the MBR.

The high number of nonsignificant results may be caused by the low sample size and thus low statistical power. However, the mean deforestation rates suggest that in conditions of low colonization pressure, long-settled community forests that are managed for timber perform equally well as or better than uninhabited protected areas. In situations of high colonization pressure, neither protected areas nor community forest management for timber in recently formed colonist communities do very well, contrary to our original hypothesis.

These findings merit further exploration of other contextual factors that likely influence the outcomes in these cases. Our observations on the context that is influencing these deforestation outcomes is based on many years of ethnographic and action-research projects in the region, as well as published literature. First, with respect to the high deforestation rates in inhabited PAs and recently inhabited communities in the MBR, also shown in the change maps, the three western MBR parks suffer from high deforestation despite repeated efforts of the government and nongovernmental organizations 
Table 2. Outputs of logistic regression analyses for Guatemala and Mexico showing the influence of the spatially independent variables used to explain deforestation rates.

\begin{tabular}{llrrrr}
\hline \hline Country & Variable & Coefficient & Coefficient SE & Wald $\chi^{2}$ & $p$ \\
\hline Guatemala & Distance to settlements & -0.632 & 0.0829 & 58.094 & $<0.0001$ \\
& Buffer zone & 5.247 & 1.0116 & 26.900 & $<0.0001$ \\
& Seasonal wetlands & -1.514 & 0.3010 & 25.286 & $<0.0001$ \\
& Inhabited multiple-use zone & 4.754 & 1.0174 & 21.833 & $<0.0001$ \\
& Inhabited protected area & 4.586 & 1.0094 & 20.644 & $<0.0001$ \\
& Recently inhabited forestry concessions & 4.036 & 1.0405 & 15.048 & $<0.0001$ \\
& Distance from roads & -0.144 & 0.0411 & 12.354 & $<0.0001$ \\
& Distance to deforested areas & -0.085 & 0.0252 & 11.519 & 0.001 \\
& Soil depth & 0.392 & 0.1377 & 8.081 & 0.004 \\
& Humid topographic index & 1.401 & 0.5192 & 7.287 & 0.007 \\
Constant & -1.676 & 1.5581 & 1.157 & 0.282 \\
& Distance to deforested areas & -1.401 & 0.045 & 971.695 & $<0.0001$ \\
& Tropical semideciduous forest & 0.838 & 0.198 & 17.875 & $<0.0001$ \\
& Protected area status & 0.130 & 0.116 & 1.259 & 0.262 \\
& Tropical forest in wetlands & -0.148 & 0.395 & 0.140 & 0.708 \\
Ejido status & -0.011 & 0.124 & 0.008 & 0.929 \\
& Constant & 7.418 & 0.337 & 483.987 & $<0.0001$ \\
\hline
\end{tabular}

directed at controlling the park borders and convincing resident peoples to adopt more sustainable livelihood patterns. In addition to colonization, other drivers of deforestation include pre-existing land claims, petroleum concessions, and contraband activities along the GuatemalaMexico border. As a probable consequence of these drivers, the logistic regression also suggested that management status (inhabited buffer zone, multiple-use zone, inhabited PAs, and recently inhabited community concessions) was related to deforestation.

The driving forces of deforestation in the three recently inhabited community concessions in the MBR appear to be somewhat different than in the inhabited PAs. In these concessions, forest loss is primarily caused by land sales to cattle ranchers and the exhaustion of high-value timber because of poor management practices, rather than new colonization, because no new communities are being formed within their boundaries. These recently inhabited community forests have not been able to sustain viable collective action around sustainable forest management despite rich stocks of mahogany and substantial incentives and organizational support in the early years. These concessions exemplify the challenges of organizing colonist communities.

The relative equivalence of deforestation in uninhabited protected areas, uninhabited concessions, and long-settled community forests have more 
Table 3. Summary of logistic regression analyses for Guatemala and Mexico showing, in both cases, a significant predictive value for future susceptibility to deforestation established by independent explanatory variables.

\begin{tabular}{|c|c|c|c|}
\hline Test statistic & & Guatemala & Mexico \\
\hline -2 log-likelihood & & 2015.955 & 2754.922 \\
\hline Cox and Snell $R^{2}$ & & 0.243 & 0.440 \\
\hline Nagelkerke $R^{2}$ & & 0.400 & 0.627 \\
\hline \multirow[t]{3}{*}{ Hosmer and Lemeshow test } & $\chi^{2}$ & 51.104 & 54.123 \\
\hline & $\mathrm{df}$ & 8 & 8 \\
\hline & $p$ & $<0.0001$ & $<0.0001$ \\
\hline
\end{tabular}

varying contextual factors. In the case of the uninhabited PAs, Calakmul demonstrated stable forest cover over a 12-yr period. Low colonization pressure, the absence of important economic interests, and stronger government institutions may account for the low deforestation rate in Calakmul (Haenn 2005, Vester et al. 2007). By contrast, the protected areas in the MBR that show low deforestation are protected by remoteness, as are the uninhabited community concessions, or their high economic value to the government and local people. The long-settled community forests also show variation between the two countries. In Mexico, the Quintana Roo ejidos represent a governance regime of multiscale forest management institutions maintained for $>20 \mathrm{yr}$ and forest cover maintenance despite a declining volume of timber production in many cases (Bray 2004). In the MBR, in contrast, the long-inhabited community forests constitute only 2 of 12 cases. They are also the most recent community concessions; are spatially removed from the active colonization frontiers, although both have roads and human populations, which, contrary to what the logistic regression suggests, are related to deforestation; and had a historical dependence on nontimber forest products, as in Quintana Roo. A major test of the viability of long-settled forest management communities to resist colonization will occur in the coming years as the colonization front moves closer to these communities.
The impact of human presence, as reflected in the land-use and land cover change maps and the variables of human settlement and previously deforested areas in the logistic regression, is also strongly conditioned by contextual variation in colonization pressure between the two countries. In Mexico, some communities have existed since the 19th century, but were formally recognized as chicle production ejidos in the 1930s. During the 1970s, they served as a bulwark against colonization, and since the mid-1980s, community land-use zoning rules have kept deforestation in prescribed agricultural areas (Bray et al. 2004). In the Calakmul region, large-scale colonization began in the 1970s, but Calakmul itself was still only lightly inhabited in 1989, when the reserve decree was superimposed over community lands (Klepeis 2004). Reserve declaration and the cessation of ejido grants after the early 1990s halted new colonization, which is evidenced by a notable reduction in deforestation during 1987-2000 compared to earlier periods (Chowdhury and Schneider 2004, Vester et al. 2007).

In contrast, in the MBR, colonization pressure remains very strong in the western and central regions. The population of the Petén increased by $>$ 20 -fold since 1960, and the current estimated population of 600,000 is expected to double in the next decade. Strong migration from the southern 
Petén into the northwestern PAs and high fertility rates inside $\mathrm{PAs}$ promise continuing forest pressures (Grandia 2006), and economically powerful actors with interest in deforestation are at work in some PAs and increasingly in some community concessions. In Guatemala, the high colonization pressure has clear spatial patterns, thus influencing spatial variability in deforestation independent of management status.

The two different management strategies appear to have significantly different costs and benefits for local communities. PAs and community forests in both countries have received varying amounts of public and private subsidies, most of which are poorly documented. In Mexico, both the ejidos and Calakmul have received substantial government and international funding in different periods, but specific data are unavailable. With respect to benefits, however, a study of forest incomes in Quintana Roo included four of the seven communities studied here and found that two of them had notable poverty alleviation effects from logging incomes (Bray et al. 2007). In contrast, in Calakmul, resource rights were denied to local communities and few direct benefits were provided except from conservation programs in the 1990s, which have now mostly disappeared (Haenn 2005), likely having a negative effect on household incomes.

For the MBR, it has been estimated that the United States Agency for International Development invested US $\$ 43.6$ million dollars in the region from 1990 to 2000 . Possibly as much as $20-40 \%$ of the investment was in community concessions (Gómez and Mendez 2005), but it is difficult to say with precision if more was invested in traditional conservation than community concessions. With respect to community benefits, community concession beneficiaries have incomes that are as much as three times higher than regional averages based only 2-3 months of work (Nittler and Tschinkel 2005). The most threatened PAs provide few legal local economic benefits except for the soil beneath the trees for invading colonists, although tourism magnets like Tikal and increasingly Yaxha and Mirador-Rio Azul provide widespread economic benefits for the Petén in general. Thus, the available data for the Maya Forest suggest that community benefits are generally much greater under community logging and the return on conservation investment may be greater as well. In the specific case of the MBR, the apparently greater investment in PAs has yielded at best a similar conservation outcome to that of community forests for timber. In both countries, PAs that are not major tourism destinations represent permanent drains on government funds, whereas community forests can finance the majority of their activities if the forest resource is large enough.

Finally, the kind of selective logging practiced in the studied Maya Forest communities does not appear to have great impacts on biodiversity, although some tradeoffs will always be present. Most tree species and faunal biodiversity, including jaguars, are little affected by logging in Quintana Roo (Ceballos et al. 2005, Vester and NavarroMartínez 2005). In the Petén, 3 yr after harvest, biodiversity impacts were minor under very-lowintensity logging (0.8-2.4 trees/ha; Radachowsky et al. 2004). As well, most community forests in both countries have Forest Stewardship Council certification.

\section{CONCLUSION}

The vast laboratory of the Maya Forest has produced a mosaic of institutions for community management for timber, strict protected areas, and other management forms, and this is a first effort to understand the differential effects of these conservation strategies on forest cover, with implications for biodiversity conservation, local income generation, and poverty alleviation. This produces a series of issues for further research, including better data on costs and benefits, monitoring of the performance of parks and community logging as well as other land uses in the multiple-use zone in the Maya Biosphere Reserve (MBR), and the varying conditions within each protected area (PA) and community forest that influence forest cover trajectories and household incomes.

Although small sample sizes may have resulted in limited statistical power in many of the comparisons, descriptive statistics on deforestation rates, logistic regression analyses, change maps, data available on local economic impacts, and observations by authors with years of ethnographic and action-research experience in the region constitute a web of evidence supporting our conclusions. In the Mexican part of the Maya Forest in conditions of low colonization pressure, PAs and community forests can be similarly effective in 
reducing deforestation, but community forests that are managed for timber appear to deliver significantly greater local benefits, a successful form of "pro-poor conservation" (Kaimowitz and Sheil 2007). In the MBR, neither poorly governed PAs nor poorly governed community forests have proven to be effective bulwarks against ongoing colonization, and it remains to be seen whether the long-inhabited community concessions will be able to resist this tide. Close monitoring and support for these communities is necessary to determine the likelihood of future forest cover protection.

Our findings suggest that community forests that are managed for timber and strict PAs can be considered complementary strategies for achieving both biodiversity conservation and local economic benefits and that each may be more or less effective under differing conditions. They also suggest that neither protected areas nor community forests can perform well in active colonization fronts. This position contrasts with statements such as "...formal protected areas have proven to be the single most reliable instrument for the protection of agricultural encroachment on habitat" (Niesten et al. 2004). Our evidence also suggests that the opposition of some conservation organizations to sustainable community logging in tropical forests as a conservation strategy should be reevaluated (Rice et al. 2001, Bray and Anderson 2005). These findings also present a useful complement to other recent studies of the relative performance of protected areas and community forests, under varying tenure arrangements, with respect to deforestation. For example, both Nepstad et al. (2006) and Hayes (2007) have suggested that long-resident indigenous communities have controlled deforestation within well-demarcated boundaries more successfully than protected areas under public management in the cases of Brazil and Nicaragua, respectively. Our research suggests that long residence in the forest (independent of ethnicity because the case studies in the Maya Forest include both indigenous and nonindigenous communities) combined with the added value of timber production may result in deforestation outcomes similar or superior to those in protected areas. However, the findings of Nepstad et al. (2006) of greater resistance to colonization vary from our findings that community lands in the Petén have been no more successful than PAs in resisting colonization. This points to the need for studies that carefully analyze the different forms of community management regimes and their relations to deforestation.
It is widely accepted that PAs can be effective in certain circumstances, including remoteness and popularity as tourist destinations. It is less recognized that the specific form of community management organized around timber production, along with other emerging forms of common property and community-based conservation, can also be effective at delivering both long-term protection and local benefits, particularly in the case of long-resident or indigenous communities (Berkes 2007). Evidence that varying forms of community management can be effective vehicles for conservation allow conservation efforts to move beyond public protected areas into larger landscapes, which is a frequently stated goal (Naughton-Treves et al. 2005). The communityforestry and protected-area hypotheses must be explored as to their validity in any given case. There are no panaceas and no single form of management is superior to others a priori for conservation and sustainable development (Ostrom and Nagendra 2006, Ostrom et al. 2007). The evidence presented here can help to move the increasingly brittle parks vs. sustainable use argument (Redford et al. 2006) onto a new plane of evidence-based policy decisions and management strategies for specific conditions.

Responses to this article can be read online at:

http://www.ecologyandsociety.org/vol13/iss2/art56/responses/

\section{Acknowledgments:}

We gratefully thank the Ford Foundation, the USAID-TIES program and project QROO-2003C02-13228 (CONACyT-Gobierno del Estado de Quintana Roo) for research funding. Technical support for image processing and digital database management for Mexico was provided by $I$. Gonzalez-Gutiérrez and J. A. Navarrete-Pacheco. Thanks go to R. R. Chowdhury, L. Grandia, N. Haenn, P. Klepeis, A. Larrazábal, and H. Nagendra for helpful comments and support.

\section{LITERATURE CITED}

Adams, W. M., R. Aveling, D. Brockington, B. Dickson, J. Elliott, J. Hutton, D. Roe, B. Vira, and W. Wolmer. 2004. Biodiversity conservation and the eradication of poverty. Science 306:1146-1149. 
Arnold, J. E. M. 1998. Managing forests as common property. FAO Forestry Paper 136. Food and Agriculture Organization, Rome, Italy. Available online at: http://www.fao.org/docrep/w8 210e/w8210e00.htm.

Berkes, F. 2007. Community-based conservation in a globalized world. Proceedings of the National Academy of Sciences 104(39):15188-15193.

Bhagwat, S., N. Brown, T. Evans, S. Jennings, and P. Savill. 2001. Parks and factors in their success. Science 293:1045-1046.

Bowles, I. A., R. E. Rice, R. A. Mittermeier, and G. A. B. da Fonseca. 1998. Logging and tropical forest conservation. Science 280:1899-1900.

Bray, D. B. 2004. Community forestry as a strategy for sustainable management: perspectives from Quintana Roo, Mexico. Pages 221-237 in D. J. Zarin, J. R. R. Alavalapati, F. E. Putz, and M. Schmink, editors. Working forests in the Neotropics: conservation through sustainable management? Columbia University Press, New York, New York, USA.

Bray, D. B., and A. B. Anderson. 2005. Global conservation non-governmental organizations and local communities. Working Paper 1. Institute for Sustainability Science in Latin America and the Caribbean, Florida International University, Miami, Florida, USA.

Bray, D. B., E. Durán Medina, L. Merino Pérez, J. M. Torres Rojo, and A. Velázquez Montes. 2007. Nueva evidencia: los bosques comunitarios de México protegen el ambiente, disminuyen la pobreza y promuevan paz social. Agrupación Sierra Madre, Mexico City, Mexico. Available online at: www.ccmss.org.mx/documentos/nuevas evidencia s folleto.pdf.

Bray, D. B., E. A. Ellis, N. Armijo-Canto, and C. T. Beck. 2004. The institutional drivers of sustainable landscapes: a case study of the 'Mayan Zone' in Quintana Roo, Mexico. Land Use Policy 21(4):333-346.

Bruner, A. G., R. E. Gullison, R. E. Rice, and G. A. B. da Fonseca. 2001. Effectiveness of parks in protecting tropical biodiversity. Science 291:125-128.

Campos, M. T., and D. C. Nepstad. 2006.
Smallholders, the Amazon's new conservationists. Conservation Biology 20(5):1553-1556.

Ceballos, G., C. Chávez, H. Garcia, and C. Manterola. 2005. Ecología y conservación del jaguar en la región de Calakmul. Biodiversitas 62:2-7.

Chowdhury, R. R., and L. Schneider. 2004. Land cover and land use: classification and change analysis. Pages 105-144 in B. L. Turner II, J. Geoghegan, and D. R. Foster, editors. Integrated land-change science and tropical deforestation in the southern Yucatán; final frontiers. Oxford University Press, Oxford, UK.

Consejo Nacional de Areas Protegidas/Wildlife Conservation Society. 2004. Estimación de la deforestación en la Reserva de Biosfera Maya, periodo 2003-2004. Unpublished report to the United States Agency for International Development, Washington, D.C., USA.

Curran, L. M., S. N. Trigg, A. K. McDonald, D. Astiani, Y. M. Hardiono, P. Siregar, I. Caniago, and E. Kasischke. 2004. Lowland forest loss in protected areas of Indonesian Borneo. Science 303:1000-1003.

Durán, E., J.-F. Mas, and A. Velázquez. 2005. Land use/cover change in community-based forest management regions and protected areas in Mexico. Pages 215-238 in D. B. Bray, L. Merino-Pérez, and D. Barry, editors. The community forests of Mexico: managing for sustainable landscapes. University of Texas Press, Austin, Texas, USA.

Ferraro, P. J., and A. Kiss. 2002. Direct payments to conserve biodiversity. Science 298:1718-1719.

Food and Agriculture Organization. 1996. Forest resources assessment 1990: survey of tropical forest cover and study of change processes. FAO Forestry Paper 130. Food and Agriculture Organization, Rome, Italy. Available online at: http://www.fao.org/ docrep/007/w0015e/w0015e00.htm.

Gibson, C. C., M. A. McKean, and E. Ostrom, editors. 2000. People and forests: communities, institutions, and governance. MIT Press, Cambridge, Massachusetts, USA.

Gómez, I., and V. E. Méndez. 2005. Asociación de comunidades forestales de Petén, Guatemala: 
contexto, logros y desafíos. Programa Salvadoreño de Investigación sobre Desarrollo y Medio Ambiente, San Salvador, El Salvador. Available online at: www.prisma2.org.sv/contenidos/svrdocu mentos/142.archivo.

Grandia, L. 2006. Unsettling: land dispossession and enduring inequity for the Q'eqchi' Maya in the Guatemalan and Belizean frontier colonization process. Dissertation. University of CaliforniaBerkeley, Berkeley, California, USA.

Gretzinger, S. P. 1998. Community forest concessions: an economic alternative for the Maya Biosphere Reserve in the Petén, Guatemala. Pages 111-124 in R. B. Primack, D. Bray, H. A. Galletti, and I. Ponciano, editors. Timber, tourists and temples: conservation and development in the Maya Forest of Belize, Guatemala, and Mexico. Island Press, Washington, D.C., USA.

Haenn, N. 2005. Fields of power, forests of discontent: culture, conservation, and the state in Mexico. University of Arizona Press, Tucson, Arizona, USA.

Hardner, J. J., and R. Rice. 1999. Rethinking forest concession policies. Pages 161-194 in K. J. Keipi, editor. Forest resource policy in Latin America. Inter-American Development Bank, Washington, D.C., USA.

Hayes, D. J., and S. A. Sader. 2001. Comparison of change-detection techniques for monitoring tropical forest clearing and vegetation regrowth in a time series. Photogrammetric Engineering and Remote Sensing 67(9):1067-1075.

Hayes, D. J., S. A. Sader, and N. B. Schwartz. 2002. Analyzing a forest conversion history database to explore the spatial and temporal characteristics of land cover change in Guatemala's Maya Biosphere Reserve. Landscape Ecology 17 (4):299-314.

Hayes, T. M. 2006. Parks, people, and forest protection: an institutional assessment of the effectiveness of protected areas. World Development 34(12):2064-2075.

Hayes, T. M. 2007. Does tenure matter? A comparative analysis of agricultural expansion in the Mosquitia Forest corridor. Human Ecology 35 (6):733-747.
Kaimowitz, D., and D. Sheil. 2007. Conserving what and for whom? Why conservation should help meet basic human needs in the tropics. Biotropica 39(5):567-574.

Klepeis, P. 2004. Forest extraction to theme parks: the modern history of land change. Pages 39-62 in B. L. Turner II, J. Geoghegan, and D. R. Foster, editors. Integrated land-change science and tropical deforestation in the southern Yucatán; final frontiers. Oxford University Press, Oxford, UK.

Mas, J.-F. 2005. Assessing protected area effectiveness using surrounding (buffer) areas environmentally similar to the target area. Environmental Monitoring and Assessment 105 (1-3):69-80.

McShane, T. O., and M. P. Wells. 2004. Getting biodiversity projects to work: towards more effective conservation and development. Columbia University Press, New York, New York, USA.

Molnar, A., S. J. Scherr, and A. Khare. 2004. Who conserves the world's forests? A new assessment of conservation and investment trends. Forest Trends and Ecoagriculture Partners, Washington, D.C., USA. Available online at: http://www.forest-trends. org/resources/publications/publications.php.

Moran, P. A. P. 1950. Notes on continuous stochastic phenomena. Biometrika 37(1-2):17-23.

Naughton-Treves, L., M. B. Holland, and K. Brandon. 2005. The role of protected areas in conserving biodiversity and sustaining local livelihoods. Annual Review of Environment and Resources 30:219-252.

Nepstad, D., S. Schwartzman, B. Bamberger, M. Santilli, D. Ray, P. Schlesinger, P. Lefebvre, A. Alencar, E. Prinz, G. Fiske, and A. Rolla. 2006. Inhibition of Amazon deforestation and fire by parks and indigenous lands. Conservation Biology 20(1):65-73.

Niesten, E. T., R. E. Rice, S. M. Ratay, and K. Paratore, editors. 2004. Commodities and conservation: the need for greater habitat protection in the tropics. Conservation International, Washington, D.C., USA. Available online at: http:/ /portal.conservation.org/portal/server.pt/gateway/ PTARGS $00293744 \quad 0 \quad 0 \quad 18 /$ Commodities\% 20\&conservation.pdf. 
Nittler, J., and H. Tschinkel. 2005. Community forest management in the Maya Biosphere Reserve of Guatemala: protection through profits. United States Agency for International Development, Washington, D.C., and Sustainable Agriculture and Natural Resource Management Collaborative Research Support Program, University of Georgia, Athens, Georgia, USA.

Ostrom, E., M. A. Janssen, and J. M. Anderies. 2007. Going beyond panaceas. Proceedings of the National Academy of Sciences 104(39):15176-15178.

Ostrom, E., and H. Nagendra. 2006. Insights on linking forests, trees, and people from the air, on the ground, and in the laboratory. Proceedings of the National Academy of Sciences 103(51):19224-19231.

Palacio-Prieto, J. L., G. Bocco, A. Velázquez, J.F. Mas, F. Takaki-Takaki, A. Victoria, L. LunaGonzález, G. Gómez-Rodríguez, J. LópezGarcía, M. Palma Muñoz, I. Trejo-Vázquez, A. Peralta Higuera, J. Prado-Molina, A. RodríguezAguilar, R. Mayorga-Saucedo, and F. González Medrano. 2000. La condición actual de los recursos forestales en México: resultados del inventario forestal nacional 2000. Investigaciones Geográficas 43:183-203. Available online at: www.igeograf.una m.mx/instituto/publicaciones/boletin/bol43/b43art11. pdf.

Primack, R. B., D. Bray, H. A. Galletti, and I. Ponciano, editors. 1998. Timber, tourists, and temples: conservation and development in the Maya Forest of Belize, Guatemala, and Mexico. Island Press, Washington, D.C., USA.

Putz, F. E., K. H. Redford, J. G. Robinson, R. Fimbel, and G. M. Blate. 2000. Biodiversity conservation in the context of tropical forest management. World Bank Biodiversity SeriesImpact Studies, Paper 75. World Bank, Washington, D.C., USA.

Radachowsky, J., R. García, M. Cordova, O. Aguirre, C. Marroquín, T. Dubón, F. Cordova, S. Funes, J. López, G. García, F. Oliva, G. Orellana, H. Tut, A. Manzaneros, E. Córdova, and P. Hernández. 2004. Effects of certified logging on wildlife in community and industrial forest concessions of northern Guatemala. Unpublished report to Wildlife Conservation Society, Consejo Nacional de Areas Protegidas, United States Agency for International Development, and Fortalecimiento Institucional en Políticas Ambientales, Guatemala City, Guatemala.

Redford, K. H., J. G. Robinson, and W. M. Adams. 2006. Parks as Shibboleths. Conservation Biology 20(1):1-2.

Rice, R. E., C. A. Sugal, S. M. Ratay, and G. A. B. da Fonseca. 2001. Sustainable forest management: a review of conventional wisdom. Advances in Applied Biodiversity Science Number 3. Center for Applied Biodiversity Science and Conservation International, Washington, D.C., USA. Available online at: science.conservation.org/ portal/server.pt/gateway/ PTARGS 012418692 $167 \quad 0 \quad 0 \quad 18 /$ aabs $\% 203 \% 20$ english.pdf.

Ruiz-Pérez, M., M. Almeida, S. Dewi, E. M. Lozano Costa, M. Ciavatta Pantoja, A. Puntodewo, A. de Arruda Postigo, and A. Goulart de Andrade. 2005. Conservation and development in Amazonian extractive reserves: the case of Alto Juruá. Ambio 34(3):218-223.

Siegel, S., and N. J. Castellan. 1995. Estadística no paramétrica aplicada a las ciencias de la conducta. Fourth edition. Trillas, Mexico City, Mexico.

Velázquez, A., E. Durán, I. Ramírez, J.-F. Mas, G. Bocco, G. Ramírez, and J.-L. Palacio. 2003. Land use-cover change processes in highly biodiverse areas: the case of Oaxaca, Mexico. Global Environmental Change 13(3):175-184.

Vester, H. F. M., D. Lawrence, J. R. Eastman, B. L. Turner II, S. Calmé, R. Dickson, C. Pozo, and F. Sangermano. 2007. Land changes in the southern Yucatán and Calakmul Biosphere Reserve: effects on habitat and biodiversity. EcologicalApplications 17(4):989-1003.

Vester, H. F. M., and M. A. Navarro-Martínez. 2005. Ecological issues in community tropical forest management in Quintana Roo, Mexico. Pages 183-214 in D. B. Bray, L. Merino-Pérez, and D. Barry, editors. The community forests of Mexico: managing for sustainable landscapes. University of Texas Press, Austin, Texas, USA.

White, A., and A. Martin. 2002. Who owns the world's forests? Forest tenure and public forests in transition. Forest Trends and Center for International Environmental Law, Washington, D. 
C., USA. Available online at: www.forest-trends.org/ documents/publications/tenurereport whoowns.pdf

von Hagen, C., editor. 2005. Using Geovis and LCCS: manual. GCP/RAF/287/ITA. Food and Agriculture Organization, Rome, Italy. Available online at: http://www.fao.org/gtos/doc/2006-GLCNFRA-INDIA/GeoVIS-2-Manual-update.pdf. 